UDC 539.3

V. M.Zelenyak ${ }^{1}$, Cand. Sc. (Tech.), Assoc. Prof., orcid.org/0000-0002-6653-4326,

L. I. Kolyasa ${ }^{1}$, Cand. Sc. (Phys.-Math.), orcid.org/0000-0002-9690-8042,

V. B. Loik ${ }^{2}$, Cand. Sc. (Tech.), orcid.org/0000-0002-3772-1640, O.D. Synelnikov ${ }^{2}$, Cand. Sc. (Tech.), orcid.org/0000-0002-0429-147X
DOI: $10.29202 /$ nvngu/2018-4/13

1 - Lviv Polytechnic National University, Lviv, Ukraine, email: kolyasa.lubov@gmail.com

2 - Lviv State University of Life Safety, Lviv, Ukraine

\title{
THERMOELASTIC STATE OF A HALF-SPACE WITH AN EDGE CRACK UNDER LOCAL HEATING CONDITIONS
}

Purpose. To determine the two-dimensional thermoelastic state in semi-infinite solids (half-space), weakened by an edge crack by the actions of local heating. Heat flow due to frictional heating on the local area of the body, causes changes in temperature and stress in the body, which significantly affects its strength, as it can lead to crack growth and local destruction. Therefore, the study of the problem of frictional heat is of practical interest. This paper proposes to investigate thermoelectromotive force intensity in the vicinity of the crack tip, depending on the local heat flux placement and orientation of cracks.

Methodology. The methods for studying two-dimensional thermoelastic state of a body with crack as stress concentrators are based on the method of complex variable function by which the problem of stationary heat conduction and thermoelasticity are reduced to singular integral equations (SIE) of the first kind, whose numerical solution was obtained by mechanical quadrature.

Findings. In this paper there are obtained graphic dependences of stress intensity factors (SIF) at the crack tip on the angle of orientation, the relative position of cracks and local region heating, the width of the region, that later on can be used to determine the critical value of the intensity of the local heat flux from equations of limit equilibrium at which crack growth and the local destruction of the body occur.

Originality. It lies in the fact that the solutions of the new two-dimensional problems of heat conduction and thermoelasticity for half-space containing an arbitrary oriented boundary crack.

Practical value. The practical value is the ability to more fully take into account the real situation in the thermostatic elements of engineering structures with cracks that operate under conditions of heat stress (frictional heat) in various industries, particularly in mining. The results of specific values of SIF at the crack tip in graphs may be useful in the development of sustainable modes of structural elements in terms of preventing the growth of cracks.

Keywords: edge crack, heat flow, thermoelasticity, frictional heating, stress intensity factor, singular integral equation

Introduction. Analysis of the recent research and publications. In the course of operation, elements of numerous structures often work under conditions of nonuniform heating, which leads to the appearance of internal temperature stresses. In the case of piecewise homogeneous bodies, even a uniform temperature distribution may lead to the appearance of these stresses due to the unequal coefficients of linear thermal expansion of components of the body. In some cases, the temperature stresses themselves or in combination with external mechanical stresses may lead to the formation of new cracks and to the propagation of the already existing cracks, i. e., cause the local or final fracture of structures or their elements. Therefore, the investigations of the distributions of temperature stresses near the crack tips in solid bodies are of high theoretical and practical significance. The results of these investigations are used for the strength analysis from the viewpoint of fracture mechanics as well as for the analyses of the serviceability and durability of structural elements with cracks. The realization of these investigations under conditions of plane problem of thermoelasticity was significantly simplified by the development of the method of singular in-

(C) Zelenyak V. M., Kolyasa L. I., Loik V. B., Synelnikov O.D., 2018 tegral equations (SIE), which proves to be one of the most convenient approaches for practical realization.

Singular integral equations are often applied in studying the stressed state of bodies with cracks. First, they were used only for very simple rectilinear and arcwise cuts. The construction of equations of this kind for systems of rectilinear cracks arbitrarily located in the elastic plane became a substantial step forward in this direction. The results obtained enabled the researchers to find the numerical and analytic solutions of the plane and antiplane problems of the theory of elasticity, the steady-state problems of heat conduction and thermoelasticity, and the problems of bending of thin plates and gently sloping shells for domains with cuts. Later, these results were generalized to the case of curvilinear cuts (cracks) and multiply connected domains with holes and cuts of any configuration. However, for homogeneous bodies with edge cracks (cuts), the problems of thermoelasticity remain poorly investigated.

Elements of many modern structures are often designed for their operation under conditions of thermal heating, such conditions contribute to emergence of thermal stresses in them. This is characteristic of tools and structures in mining industry. Their operability, to a great extent, is determined by the level of concentration 
and intensity of these stresses on some regions, for example, in a neighbourhood of non-homogeneities of technological nature (cracks, inclusions). With this, the fracture of materials is caused by the presence of sharp concentrators of stresses such as cracks. Therefore, the study of thermoelastic state near a crack is necessary for calculations of strength from the point of view of fracture mechanics, which is especially important for structures with highly strong and of low plastic materials which are under the action of different kinds of heat loadings.

The stationary problem of heat conduction and thermoelasticity for an infinite body with two identical coplanar thermally active circular cracks is solved. By using harmonic potentials of a simple and double layer, the problem to singular integral equations with regular kernels is reduced [1].

This paper [2] deals with the thermoelasticity problem of bonded dissimilar half-planes with a functionally graded interlayer, weakened by a pair of two offset interfacial cracks. The cracks are assumed to be thermally insulated disturbing a steady-state uniform heat flow, and the solution is obtained within the framework of linear plane thermoelasticity. The Fourier integral transform method is employed, and the formulation of the current nonisothermal crack problem is reduced to two sets of Cauchy-type singular integral equations for temperature and thermal stress fields in the bonded system. In the numerical results, parametric studies are conducted so that the variations in mixed-mode thermal stress intensity factors are presented as a function of offset crack distance for various geometric and material combinations of the dissimilar homogeneous media bonded through the thermoelastically graded interlayer, elaborating thermally induced singular interaction of the two neighbouring interfacial cracks.

Dynamic steady-state growth in 3D of a semi-infinite plane brittle crack in a coupled thermoelastic solid is considered. Compressive loads cause growth by translating on the crack surfaces at constant, subcritical speed. An asymptotic solution is obtained in an analytic form and subjected to a criterion of the Griffith type for the case of a compressive point force. The exact solution to a nonlinear differential equation indicates a rectilinear crack edge deformed by a bulge near the point force. Temperature change near the crack edge is examined in terms of a mathematical norm [3].

The multiple cracks problem in an elastic half-plane is formulated into a singular integral equation using the modified complex potential with free traction boundary condition. A system of singular integral equations is obtained with the distribution dislocation function as unknown, and the traction applied on the crack faces as the right hand terms in the paper [4].

In the paper [5] the problem of the stress concentration in the vicinity of the crack tips for a crack of finite length located perpendicular to the interface of two elastic bodies - a half-plane and a strip is considered. Using the method of generalized integral transforms, the problem reduces to solution of a singular integral equation with a Cauchy kernel. Limit cases of the problem are considered when the thickness of the strip is relatively small, equal to zero (free boundary of the half-plane), or indefinitely large (a composite plane). The solution of the integral equation is constructed by the collocation method and the small parameter method. With the aim of increasing the efficiency of the numerical method, an approximation of the regular part of the kernel in a special form is used. Values of the stress intensity factors of the normal stresses in the vicinity of crack tips are obtained for different combinations of the geometrical and physical parameters of the problem.

The cracks which are formed in the course of sliding contact are one of the most widespread causes of fracture of solids in mechanical gearing structure which are used in different branches of industry, in particular, in mining industry. It is known, that one of the factors of initiation and propagation of contact cracks is temperature and its gradients due to frictional heat generation at the sliding contact.

In the paper [6] the solutions of the thermoelasticity problem for a plane with a crack and a graded interphase zone in the connected materials are presented. The thermal influence on the growth of a crack with different thermal and mechanical conditions on the basis of the edge method (ES-FEM) was studied; this method is more precise than the standard finite element method (FEM).

The two-dimensional problems of thermoelasticity for semiinfinite bodies with cracks have already been investigated in literature. Thus, in particular, the method of SIE was used for the analysis of the plane thermoelastic state in a half space locally heated over a part of its free surface by a heat flow and containing an internal rectilinear crack [7].

Local frictional heating of surface of a half-space containing a curvilinear crack in stationary state was investigated in the paper [8], and that with an inclusion and a crack was studied in [9-11]. In this paper, a thermal problem of friction for elastic half-space weakened by a single edge crack is considered.

The heat problem of friction is reduced to finding the temperature and the stress fields in the solid caused by the given heat flux of the intensity $q$ on the contact region of its boundary. The heat flux $q$ is assumed to be proportional to the frictional work. Using Amonton's law the friction work is defined as a product of friction coefficient $f$, sliding speed $V$, and contact pressure $p$, where the distribution of the contact pressure is assumed to be known from the solution of the corresponding isothermal problem. According to Johnson's remark, the distribution of contact pressure is often taken as a constant. Thus, the thermoelastic half-space with an edge crack is assumed to be heated by a heat flux of constant intensity in the contact region. The edge crack of the length $2 b$ is inclined at the angle $\omega$ to the boundary plane. The dependencies of stress intensity factors on the geometrical parameters (angle of crack orientation $\omega$, half-length of crack $b$, half-width of heating zone $a$, distance $d$ from the centre of heating region to the axes $O y$ which passes the centre of the crack) are investigated. The results are presented in the form of graphs. 
Formulation of the problem. In the section the problem of single edge crack in the elastic half-space subjected to the frictional heating is formulated.

An elastic half-space containing a single edge crack is assumed to be subjected to sliding contact by a rigid punch with a constant speed $V$. The geometry and coordinate system of the considered problem is shown in Fig. 1. The semi-infinite body is referred to the rectangular-coordinate system $(x, y)$. The coordinates $x^{\prime}=x+d$, $y=y$ are fixed to the centre of the contact region. The supplementary rectangular coordinate system $\left(x_{1}, y_{1}\right)$, whose origin $O_{1}$ is located at the centre of crack will be also applied. The relation between the two coordinate systems $(x, y)$ and $\left(x_{1}, y_{1}\right)$ is given by

$$
z_{1}=(z+i h) \exp (-i \omega)
$$

where $z=x+i y, z_{1}=x_{1}+i y_{1}, h=b \sin \omega$.

Assuming that the total work done by the friction is transformed into the thermal energy, the part $\left|x^{\prime}\right| \leq a$ of the bounding plane $y^{\prime}=0$, is subjected to a frictional heat input

$$
q=\lambda f V p,
$$

where $\lambda$ is the coefficient of heat flux separation.

The remaining region $\left|x^{\prime}\right|>a, y^{\prime}=0$ is assumed to be thermally insulated and the temperature gradients at infinity equals zero.

The stress field $\sigma_{i j}$ in the presented problem is given as the sum of two stress fields

$$
\sigma_{i j}=\sigma_{i j}^{0}+\sigma_{i j}^{*},
$$

where $\sigma_{i j}^{0}$ denotes the total stresses in the half-space without crack subjected to the sliding contact loading with the heat flux $q$ given by equation (1) in the contact region. The stresses $\sigma_{i j}^{*}$ denote the disturbances induced by the edge crack. The stress field $\sigma_{i j}^{0}$ results from the mechanical contact pressure and from the thermal stresses arising from frictional heating caused by thermal distortion of the surface profiles of the contacting bodies.

The boundary conditions on the boundary plane of the half-space are the following:

- thermal

$$
\left.K \frac{\partial T}{\partial y^{\prime}}\right|_{y^{\prime}=0}=\left\{\begin{array}{cc}
-q, & \text { for }\left|x^{\prime}\right| \leq a \\
0, & \text { for }\left|x^{\prime}\right|>a
\end{array} ;\right.
$$

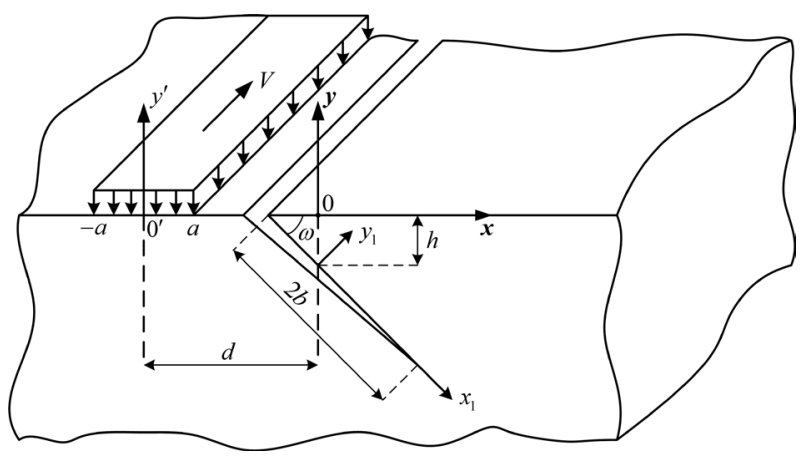

Fig. 1. Schematic diagram of the frictional heating of half-space with the edge crack [12]
- mechanical

$$
\sigma_{y y}(x, 0)=0 ; \quad \sigma_{x y}(x, 0)=0, \quad|x|<\infty .
$$

Assuming that the surfaces of the crack are thermoinsulated and the friction on the crack surfaces is neglected, the boundary conditions on the crack may be written in the form:

- thermal

$$
\left.\frac{\partial T}{\partial y_{1}}\right|_{y_{1}=0^{+}}=0 ;\left.\quad \frac{\partial T}{\partial y_{1}}\right|_{y_{1}=0^{-}}=0, \quad\left|x_{1}\right| \leq b ;
$$

- mechanical

$$
\sigma_{y_{1} y_{1}}\left(x_{1}, 0 \pm\right)=0 ; \quad \sigma_{x_{1} y_{1}}\left(x_{1}, 0 \pm\right)=0, \quad\left|x_{1}\right| \leq b .
$$

Moreover, the conditions at the infinity

$$
\mathrm{T} \rightarrow 0 ; \quad \sigma_{i j} \rightarrow 0, \text { for } \sqrt{x^{2}+y^{2}} \rightarrow \infty,
$$

are satisfied. The subscripts denote the limit values of the corresponding quantities from the left and from the right of the positive direction of the crack axis.

Temperature distribution. The section contains an analysis of temperature field in the body. The temperature distribution is determined by the derivative of temperature jump on the crack surfaces, which has to be found from the derived singular integral equation. The temperature field $T(x, y)$ in the half-space is also divided into two temperature fields as follows

$$
T(x, y)=T_{0}(x, y)+T^{*}(x, y),
$$

where $T_{0}(x, y)$ denotes the temperature in the uncracked half-space caused by the frictional heat flux $q$. The temperature $T^{*}(x, y)$ determines the perturbated temperature field induced by the edge crack.

The stationary solution in the uncracked half-space under the frictional heat flux $q$ given in equation (1) is presented in the form

$$
\begin{gathered}
T_{0}(x, y)=-\frac{1}{\pi K} \int_{-a}^{a} q \ln \sqrt{\left(x^{\prime}-\xi\right)^{2}+y^{\prime 2}} d \xi= \\
=\frac{q}{\pi K}\left\{(x+d-a) \ln \sqrt{(x+d-a)^{2}+y^{2}}-\right. \\
\left.+y\left[\operatorname{arctg}\left(\frac{x+d-a}{y}\right)-\operatorname{arctg}\left(\frac{x+d+a}{y}\right)\right]+2 a\right\}+c,
\end{gathered}
$$

where $c$ is an arbitrary constant.

To determine the perturbated temperature $T^{*}(x, y)$ caused by the crack, the complex potential $\theta(z)$ of temperature function related with the temperature $T^{*}(x, y)$ by the following relation

$$
T^{*}(x, y)=\operatorname{Re} \theta(z)
$$

will be applied.

The derivative of the potential $\theta^{\prime}(z)$ is taken into account in the form 


$$
\begin{gathered}
\theta^{\prime}(z)=\frac{1}{\pi i} \int_{-b}^{b}\left(\frac{1}{\tau_{1}-z}-\frac{1}{\bar{\tau}_{1}-z}\right) \gamma^{\prime}\left(t_{1}\right) d t_{1} ; \\
\tau_{1}=t_{1} \exp (i \omega)-i h,
\end{gathered}
$$

where $\bar{\tau}_{1}$, denotes the conjugate value of $\tau_{1}$, and $\gamma\left(t_{1}\right)$ is the temperature jump at the crack surfaces

$$
2 \gamma\left(x_{1}\right)=T^{*}\left(x_{1}, 0^{+}\right)-T^{*}\left(x_{1}, 0^{-}\right),
$$

and $\gamma^{\prime}\left(t_{1}\right)$ is the derivative of the function $\gamma\left(t_{1}\right)$.

By substituting the solution (3) and equalities $(4,5)$ into the boundary condition (2), the following singular integral equation for the unknown function $\gamma^{\prime}\left(x_{1}\right)$ is obtained

$$
\int_{-1}^{1} L(\xi, \eta) \gamma^{\prime}(\xi) d \xi=\pi F(\eta), \quad|\eta|<1
$$

where

$$
\begin{gathered}
L(\xi, \eta)=\frac{1}{\xi-\eta}+\frac{(2+\xi+\eta) \sin ^{2} \omega-(\xi-\eta) \cos ^{2} \omega}{(2+\xi+\eta)^{2} \sin ^{2} \omega-(\xi-\eta)^{2} \cos ^{2} \omega} ; \\
F(\eta)=\left.\sin \omega \frac{\partial T_{0}(x, y)}{\partial x}\right|_{y_{1}=0}-\left.\cos \omega \frac{\partial T_{0}(x, y)}{\partial y}\right|_{y_{1}=0} ; \\
\xi=t_{1} / b ; \quad \eta=x_{1} / b ; \quad \gamma^{\prime}(\xi) \equiv \gamma^{\prime}(b \xi) b .
\end{gathered}
$$

We note that the condition of continuity of the temperature $T^{*}$ along the crack contour

$$
\int_{-b}^{b} \gamma^{\prime}\left(t_{1}\right) d t_{1}=0
$$

which holds for the case of subsurface crack is not satisfied for the edge crack.

Thermal stresses. In the section the singular integral equation for jumps of displacement vector on the crack surfaces is presented. Thus, the considered problem is reduced to the solution of a system of three singular integral equations for jumps of temperature and displacements. The temperature $T_{0}$ does not produce the stresses in the uncracked half-space. For calculation of the stresses $\sigma_{i j}^{*}$ caused by the temperature $T^{*}$ the following singular integral equation (SIE) is derived [9]

$$
\int_{-1}^{1}\left[R(\xi, \eta) g^{\prime}(\xi)+S(\xi, \eta) \overline{g^{\prime}(\xi)}\right] d \xi=P(\eta),|\eta|<1,
$$

where

$$
\begin{gathered}
R(\xi, \eta)=\frac{1}{\xi-\eta}+\frac{1}{2} \times\left\{\frac{1}{1+\eta-(1+\xi) \exp (2 i \omega)}+\right. \\
+\frac{(1+\eta)^{2}+(1+\xi)(1+\eta)[1-4 \exp (-2 i \omega)+\exp (-4 i \omega)]}{[1+\eta-(1+\xi) \exp (-2 i \omega)]^{3}}+ \\
\left.+\frac{(1+\xi)^{2}[\exp (-2 i \omega)-\exp (-4 i \omega)-\exp (-6 i \omega)]}{[1+\eta-(1+\xi) \exp (-2 i \omega)]^{3}}\right\} ;
\end{gathered}
$$

$$
\begin{gathered}
S(\xi, \eta)=\frac{1+\xi}{2}\left\{\frac{1-\exp (-2 i \omega)}{[1+\eta-(1+\xi) \exp (-2 i \omega)]^{2}}+\right. \\
+\frac{\exp (2 i \omega)[1-\exp (2 i \omega)]}{\left.[1+\eta-(1+\xi) \exp (2 i \omega)]^{2}\right]} ; \\
P(\eta)=i \beta \int_{-1}^{1}[S(\xi, \eta)-R(\xi, \eta)] \gamma(\xi) d \xi ; \\
\gamma(\xi)=\int \gamma^{\prime}(\xi) d \xi+C ; \\
G(\xi)=g^{\prime}(\xi)+i \beta \gamma(\xi) ; \quad \beta=\frac{\alpha \mu(1+v)}{1-v} ; \\
g^{\prime}(\xi) \equiv g^{\prime}(l \xi) \cdot b ; \\
g(\xi)=\frac{\mu}{2 i(1-v) \frac{\partial}{\partial \xi}\left\{u\left(\xi, 0^{+}\right)-u\left(\xi, 0^{-}\right)+\right.} \\
\left.+i\left[v\left(\xi, 0^{+}\right)-v\left(\xi, 0^{-}\right)\right]\right\},
\end{gathered}
$$

and $u, v$ are the displacements in the directions of the axes $O x_{1}$, and $O y_{1}$, respectively.

It is necessary to note that the condition of the single-valuedness of the displacements along the crack contour

$$
\int_{-1}^{1} G(\xi) d \xi=-i \beta \int_{-1}^{1} \xi \gamma^{\prime}(\xi) d \xi
$$

which takes the place in the case of the subsurface crack is not satisfied for the edge crack.

Numerical algorithm. The section contains the presentation of numerical method of solution of the integral equations and the expression of stress intensity factors as functions of the jumps of temperature and displacements. The kernels of singular integral equations (6) and (7) have the singularities of Cauchy type and, besides, the immovable singularities at the points $\xi=\eta=$ $=-1$. In this case, the functions $\gamma^{\prime}(\xi)$ and $g^{\prime}(\xi)$ have a singularity which is different from $\xi^{-\frac{1}{2}}$ at the point $\xi=-1\left(x_{1}=0\right)$. The character of the singularity can be determined by analysis of the functions $L(\xi, \eta), R(\xi, \eta)$ and $S(\xi, \eta)$. Next, the singular integral equations (6) and (7) can be solved by using the numerical method based on Gauss - Jacobi quadrature rule. However, this method is complicated. In the paper, a simplified approach of the numerical solving of equations (6) and (7) is applied. For this purpose, the functions $\gamma^{\prime}(\xi), g^{\prime}(\xi)$ are taken in the form

$$
\gamma^{\prime}(\xi)=\frac{\gamma_{0}(\xi)}{\sqrt{1-\xi^{2}}} ; \quad g^{\prime}(\xi)=\frac{g_{0}(\xi)}{\sqrt{1-\xi^{2}}}, \quad|\xi|<1,
$$

where $\gamma_{0}(\xi), \gamma_{0}(\xi)$ are the unknown functions. By using the method of Gauss - Chebyshev quadrature rule, from the singular integral equations (6) and (7), two systems of $(n-1)$ linear algebraic equations, $(n-1)$ equa- 
tions in each, for $n$ unknown $g_{0}\left(\xi_{k}\right), k=1,2, \ldots, n$ is obtained

$$
\begin{gathered}
\frac{1}{n} \sum_{k=1}^{n} L\left(\xi_{k}, \eta_{m}\right) \gamma_{0}\left(\xi_{k}\right)=F\left(\eta_{m}\right) ; \\
m=1,2, \ldots, n-1 ; \\
\frac{1}{n} \sum_{k=1}^{n}\left[R\left(\xi_{k}, \eta_{m}\right) g_{0}\left(\xi_{k}\right)+S\left(\xi_{k}, \eta_{m}\right) \overline{g_{0}\left(\xi_{k}\right)}\right]=P\left(\eta_{m}\right) ; \\
m=1,2, \ldots, n-1,
\end{gathered}
$$

where $P\left(\eta_{m}\right)=i \beta \sum_{k=1}^{n}\left[S\left(\xi_{k}, \eta_{m}\right)-R\left(\xi_{k}, \eta_{m}\right)\right] \gamma\left(\xi_{k}\right)$;

$\xi_{k}=\cos [(2 k-1) \pi /(2 n)] ; \eta_{m}=\cos \frac{\pi m}{n}$.

From physical assumption it follows that $\gamma_{0}(-1)=0$, $g_{0}(-1)=0$, since the functions $\gamma_{0}(\xi), \gamma_{0}(\xi)$ at the point $\xi=-1$ (corresponds to the crack tip $x_{1}=-b$ ) must have a singularity of lower order than $(1+\xi)^{-\frac{1}{2}}$. For $\gamma_{0}(-1)$, $\gamma_{0}(-1)$, the following algebraic equations are obtained

$$
\begin{aligned}
& \sum_{k=1}^{n}(-1)^{k} \gamma_{0}\left(\xi_{k}\right) \operatorname{tg}\left(\frac{2 k-1}{4 n} \pi\right)=0 ; \\
& \sum_{k=1}^{n}(-1)^{k} g_{0}\left(\xi_{k}\right) \operatorname{tg}\left(\frac{2 k-1}{4 n} \pi\right)=0 .
\end{aligned}
$$

From the solution of the system of $n$ linear algebraic equations (8) and (10) we obtain the functions $\gamma_{0}\left(\xi_{k}\right)$, $k=1,2, \ldots, n$. The function $\gamma_{0}(\xi)$ can be presented in the form of interpolated polynomial

$$
\gamma_{0}(\xi)=\frac{2}{n} \sum_{k=0}^{n-1} \sum_{m=1}^{n} \cos \left(\frac{2 m-1}{2 n} k \pi\right) \gamma_{0}\left(\xi_{m}\right) \mathrm{T}_{k}(\xi),
$$

where $T_{k}(\xi)$ is the Chebyshev polynom of the first kind of the order $k$.

The determinate of the temperature jump $\gamma\left(\xi_{k}\right)$ from the solution of the system of equation (8) and (10) enables us to solve the system of $n$ linear algebraic equations (9) and (11). Then, the stress intensity factors (SIFs) at the point $\xi=1, x_{1}=b$ being the crack tip can be given in the form

$$
k_{1}-i k_{2}=\sqrt{b / 2} \frac{1}{n} \sum_{k=1}^{n}(-1)^{k} g_{0}\left(\xi_{k}\right) \operatorname{ctg}\left(\frac{2 k-1}{4 n} \pi\right) .
$$

Analysis of the problem. The final remarks and conclusions are presented in this section and the next section. From the point of view of the fracture mechanics, the determination of the stress intensity factors $k_{1}$ and $k_{2}$ is a fundamental problem for a prognosis of the crack propagation. As a result of the carried out calculations, it was shown that the SIFs satisfy the inequality $k_{1} \ll k_{2}$, so a fundamental numerical consideration is devoted to the dimensionless stress intensity factor $k_{2}^{*}$ described by

$$
k_{2}^{*}=\frac{\sqrt{\pi} K k_{2}}{q \beta b \sqrt{b}} .
$$

The independent input data of the considered problem are the values $\omega, d^{*}=d / h, a^{*}=a / h$ and $b^{*}=b / h$. The parameter $b^{*}$ is fixed, and it is assumed that $b^{*}=1$. The SIF $k_{2}$, which characterizes the intensity of shear stresses at the crack tip $x_{1}=b$, increases when the crack tip $x_{1}=b$ tends to the boundary plane of the half-space (Fig. 2). For every distance $d^{*}$ of the crack centre from the centre of heating region there exists the angle $\omega^{*}$ for which $k_{2}^{*}=0$.

The dependence of $\omega^{*}$ with respect of the parameter $d^{*}$ is shown in Fig. 3 (solid curve). These results are approximated by the following function

$$
\omega^{*}=13 d^{* 2}-41.5 d^{*}+90,
$$

and it is presented as the dashed curve in Fig. 3. It is seen that with the increase in the distance from the crack to the contact region, the value of the angle $\omega^{*}$ decreases, Fig. 3.

If the inclination angle is fixed, then the behaviour of $k_{2}$ for increasing of $d^{*}$ is dependent on the parameter $\omega$, Fig. 4. For $0^{\circ}<\omega<90^{\circ}$, the increase in $d^{*}$ leads to both an increase in and a decrease in $\left|k_{2}^{*}\right|$. For $90^{\circ}<\omega<170^{\circ}$, it can be observed that $\left|k_{2}^{*}\right|$ decreases monotonely with the increase in $d^{*}$.

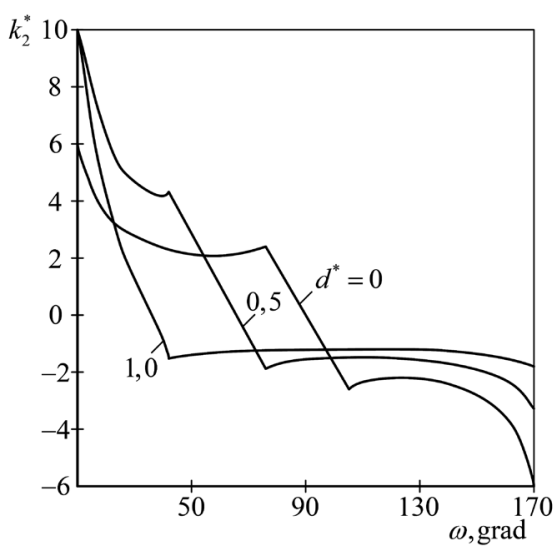

Fig. 2. Dependence of dimensionless SIF $k_{2}^{*}$ on crack orientation angle at different values of $d^{*}$ and $a^{*}=0.25$ [12]

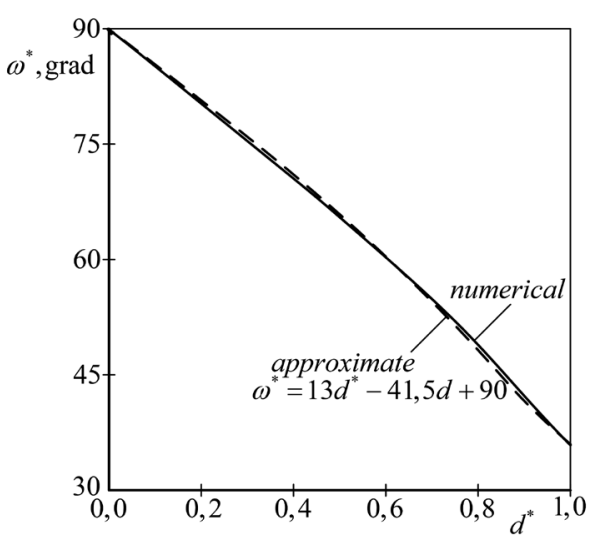

Fig. 3. Dependence of crack orientation angle on parameter $d^{*}$ and $a^{*}=0.25$ under which $k_{2}^{*}=0$ (continuous curve represents the numerical solutions, dashed curve represents the approximated equation (12)) 
It is see that the increase in the width of the heating region (parameter $a^{*}$ ) leads to a linear increase in $k_{2}$, Fig. 5. Moreover, for each fixed inclination angle of crack there exists a critical value of $a^{*}$ such that further increasing of $a^{*}$ does not lead to changing of $k_{2}^{*}$.

Conclusions. The presented analysis enables us to conclude that the variation of the SIF $k_{2}$ in the case of edge crack has different character from that for the SIF $k_{2}$ in the case of subsurface crack:

- $\left|k_{2}^{*}\right|$ for the edge crack is considerably greater than $\left|k_{2}^{*}\right|$ for the subsurface crack;

- there exists a critical value of the width of heating region such that its further increase does not lead to the increase in $k_{2}^{*}$;

- for the case of single edge crack, the SIF $k_{1}^{*}$, is significantly less than the SIF $k_{2}^{*}$, i.e. $k_{1} \ll k_{2}$. This inequality is not satisfied in the case of the problem of subsurface crack.

Moreover, for the subsurface crack it is shown that for fixed parameters $d^{*}$ and $a^{*}$ there exists a value of inclination angle of crack for which $k_{2}^{*}=0$. In this case, the frictional heating does not cause stresses in the body with crack.

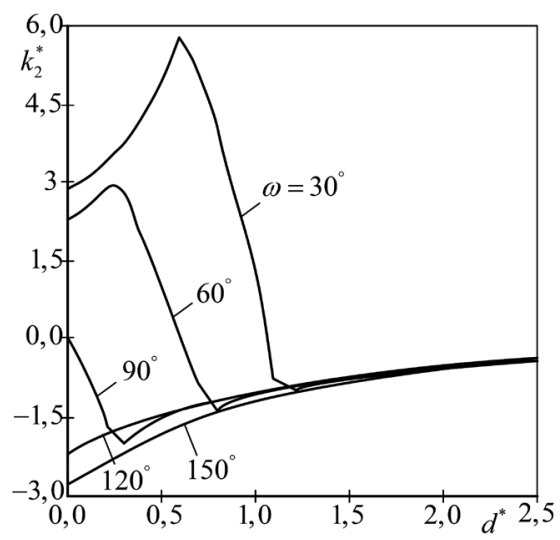

Fig. 4. Dependence of SIF $k_{2}^{*}$ on parameter $d^{*}$ for different values of angle $\omega$ and at $a^{*}=0.25$ [12]

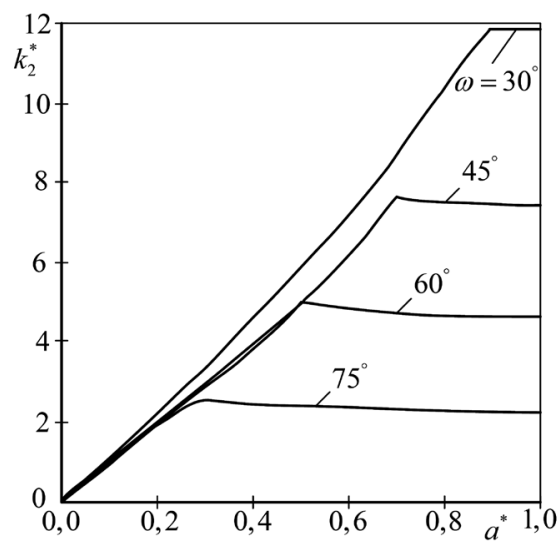

Fig. 5. Dependence of SIF $k_{2}^{*}$ on parameter $a^{*}$ for symmetric heating $d^{*}=0$ and different values of $\omega$ [12]

\section{References.}

1. Sushko, O.P., 2013. Thermoelastic state of a body with two coplanar thermally active circular cracks. Journal of Mathematical Sciences, 190(5), pp. 725-739.

2. Choi, H.J., 2014. Thermoelastic interaction of two offset interfacial cracks in bonded dissimilar half-planes with a functionally graded interlayer. Acta Mechanica, 225(7), pp. 2111-2131.

3. Brock, L. M., 2016. Contours for planar cracks growing in three dimensions: Coupled thermoelastic solid (planar crack growth in 3D). Journal of Thermal Stresses, 39(3), pp. 345-359. DOI: 10.1080/01495739.2015.1125656.

4. Elfakhakhre, N. R. F., Nik long, N. M.A. and Eshkuvatov, Z. K., 2017. Stress intensity factor for multiple cracks in half plane elasticity. AIP Conference, 1795(1). DOI: $10.1063 / 1.4972154$.

5. Rashidova, E. V. and Sobol, B. V., 2017. An equilibrium internal transverse crack in a composite elastic half-plane. Journal of Applied Mathematics and Mechanics, 81(3), pp. 236-247. DOI:10.1016/j.jappmathmech.2017.08.016.

6. Chen, H., Wang, Q., Liu, G.R., Wang, Y. and Sun, J., 2016. Simulation of thermoelastic crack problems using singular edge-based smoothed finite element method. International Journal of Mechanical Sciences, 115-116, pp. 123-134. DOI: 10.1016/j.ijmecsci.2016.06.012.

7. Kit, G.S. and Ivas'ko, N. M., 2013. Plane deformation of a semi-infinite body with a heat-active crack perpendicular to its boundary. Teoret. I prikl. Mehanika, 53(7), pp. 30-37.

8. Zelenyak, V. M. and Kolyasa, L. I., 2016. Thermoelastic state of a half plane with curvilinear crack under the conditions of local heating. Materials Science, 52(3), pp. 315-322.

9. Zelenyak, V. M., 2014. Investigation of the thermoelastic state of two-dimensional composite bodies with cracks. Materials Science, 50(1), pp. 14-19.

10. Havrysh, V. I., 2017. Investigation of temperature fields in a heat-sensitive layer with through inclusion. Materials Science, 52(4), pp. 514-521.

11. Havrysh, V.I., 2015. Nonlinear boundary-value problem of heat conduction for a layred plate with inclusion. Materials Science, 51(3), pp. 331-339.

12. Savruk, M.P. and Zelenyak, V.M., 2009. Two-dimensional problems of thermoelasticity for piecewise- homogeneous bodies with cracks (monograph). Lviv: Rastr-7 [pdf]. Available at: <http://www.irbis-nbuv.gov.ua/cgibin/irbis64r_81/cgiirbis_64.exe?I21DBN=VFEIR\&P21 $\mathrm{DBN}=\mathrm{VFE} \overline{\mathrm{I}} \& \mathrm{Z} 21 \mathrm{ID}=\& \mathrm{~S} 21 \mathrm{REF}=10 \& \mathrm{~S} 21 \mathrm{CNR}=20 \&$ $\mathrm{S} 21 \mathrm{STN}=1 \& \mathrm{~S} 21 \mathrm{FMT}=$ fullwebr $\& \mathrm{C} 21 \mathrm{COM}=\mathrm{S} \& 2$ $\mathrm{S} 21 \mathrm{P} 03=\mathrm{A}=\& 2 \_\mathrm{S} 21 \mathrm{STR}=\% \mathrm{D} 0 \% 97 \% \mathrm{D} 0 \% 95 \% \mathrm{D} 0 \% 9 \overline{\mathrm{B}}$ $\%$ D $0 \% 95 \%$ D $0 \% 9$ D \% D $0 \%$ A F \% D $0 \% 9$ A \% 20 $\% \mathrm{D} 0 \% 92 \% 2 \mathrm{E} \% 20 \% \mathrm{D} 0 \% 9 \mathrm{C} \% 2 \mathrm{E}>$ [Accessed 14 May 2017].

\section{Термопружний стан півпростору з крайовою тріщиною за умов локального нагрівання}

\author{
В. М. Зеленяк ${ }^{1}$, Л. І. Коляса ${ }^{1}$, В. Б. Лоїк \\ О.Д. Синельніков ${ }^{2}$
}


1 - Національний університет „Львівська політехніка“, м. Львів, Україна, e-mail: kolyasa.lubov@gmail.com

2 - Львівський державний університет безпеки життєдіяльності, м. Львів, Україна

Мета. Визначення двовимірного термопружного стану в напівнескінченному твердому тілі (півпросторі), послабленому крайовою тріщиною за дії локального нагрівання. Тепловий потік, обумовлений фрикційним нагріванням на локальній ділянці тіла, спричиняє зміну температури й напружень у тілі, що значно впливає на його міцність, оскільки може призвести до росту тріщини й локального руйнування. Тому вивчення проблеми фрикційного нагрівання має практичний інтерес. У цій роботі пропонується дослідити інтенсивність термонапружень в околі вершини тріщини в залежності від локального розміщення теплового потоку та орієнтації тріщини.

Методика. Методика вивчення двовимірного термопружного стану тіла з тріщиною, як концентратором напружень, базується на методі функції комплексної змінної, за допомогою якого задачі стаціонарної теплопровідності й термопружності зведено до сингулярних інтегральних рівнянь (СIP) першого роду, числовий розв'язок яких одержано методом механічних квадратур.

Результати. У роботі отримані графічні залежності коефіцієнтів інтенсивності напружень (KIH) у вершині тріщини від кута ії̈ орієнтації, від взаємного розміщення тріщини й локальної ділянки нагрівання, від ширини цієї ділянки, що в подальшому можна використати для визначення критичного значення інтенсивності локального теплового потоку із рівнянь граничної рівноваги, за якого починається зростання тріщини й локальне руйнування тіла.

Наукова новизна. Полягає в тому що отримані розв'язки нових двовимірних задач теплопровідності й термопружності для півпростору, що містить довільну орієнтовану крайову тріщину.

Практична значимість. Полягає в можливості повнішого врахування реального термопружного стану в елементах інженерних конструкцій із тріщинами, що працюють за умов теплових навантажень (фрикційного теплоутворення) в різних галузях промисловості, зокрема й у гірничорудній. Результати конкретних значень КІН у вершині тріщини у вигляді графіків можуть бути корисними при розробці раціональних режимів роботи елементів конструкцій з погляду недопущення зростання тріщин.

Ключові слова: крайова тріщина, тепловий потік, термопружність, фрикційне нагрівання, коефіцієнт інтенсивності напружень, сингулярне інтегральне рівняння

\section{Термоупругое состояние полупространства с краевой трещиной в условиях локального нагрева}

\author{
В. М. Зеленяк ${ }^{1}$, Л. И. Коляса ${ }^{1}$, В. Б. Лоик ${ }^{2}$, \\ О.Д. Синельников
}

1 - Национальный университет „Львовская политехника““, г. Львов, Украина, e-mail: kolyasa.lubov@gmail.com 2 - Львовский государственный университет безопасности жизнедеятельности, г. Львов, Украина

Цель. Определение двумерного термоупругого состояния в полубесконечном твердом теле (полупространстве), ослабленном краевой трещиной при действии локального нагрева. Тепловой поток, обусловленный фрикционным нагревом на локальном участке тела, вызывает изменение температуры и напряжений в теле, что значительно влияет на его прочность, поскольку может привести к росту трещины и локальному разрушению. Поэтому изучение проблемы фрикционного нагрева имеет практический интерес. В этой работе предлагается исследовать интенсивность термонапряжений в окрестности вершины трещины в зависимости от локального размещения теплового потока и ориентации трещины.

Методика. Методика изучения двумерного термоупругого состояния тела с трещиной, как концентратором напряжений, базируется на методе функции комплексной переменной, с помощью которого задачи стационарной теплопроводности и термоупругости сведены к сингулярным интегральным уравнениям (СИУ) первого рода, числовое решение которых получено методом механических квадратур.

Результаты. В работе получены графические зависимости коэффициентов интенсивности напряжений (КИН) в вершине трещины от угла ее ориентации, от взаимного расположения трещины и локального участка нагрева, от ширины этого участка, что в дальнейшем можно использовать для определения критического значения интенсивности локального теплового потока из уравнений предельного равновесия, при котором начинается рост трещины и локальное разрушение тела.

Научная новизна. Заключается в том, что получены решения новых двумерных задач теплопроводности и термоупругости для полупространства, которое содержит произвольно ориентированную краевую трещину.

Практическая значимость. Заключается в возможности более полного учета реального термоупругого состояния в элементах инженерных конструкций с трещинами, которые работают в условиях тепловых нагрузок (фрикционного теплообразования) в различных отраслях промышленности, в том числе и в горнорудной. Результаты конкретных значений КИН в вершине трещины в виде графиков могут быть полезными при разработке рациональных режимов работы элементов конструкций с точки зрения недопущения роста трещин.

Ключевые слова: краевая трещина, тепловой поток, термоупругость, фрикционной нагрев, коэффициент интенсивности напряжсений, сингулярное интегральное уравнение

Рекомендовано до публікації докт. фіз.-мат. наук Р. С. Мусієм. Дата надходження рукопису 05.06.17. 